\title{
EMPATIA W SZTUCE - DAWNIEJ I DZIŚ
}

Profesor Wandzie Nowakowskiej, której wykłady z historii sztuki stanowiq praktycznq lekcję empatii

@ łowo „empatia” zostało wprowadzone do języka angielskiego w $1909 \mathrm{r}$. przez psychologa Edwarda Titchenera jako tłumaczenie niemieckiego wyrazu Einfühlung, który dosłownie oznaczał wczucie (feeling into) ${ }^{1}$. Angielska wersja terminu została przyjęta w różnych dziedzinach wiedzy, choć dzisiaj czasami wskazuje się, że właściwy obszar jej zastosowania stanowi psychologia społeczna. Empatia pojmowana jest wówczas jako:

obiektywne rozumienie innego [człowieka] poprzez wysiłek przeniknięcia intelektualnego świata jego przeżyć, ale bez partycypacji afektywnej, pozytywnej lub negatywnej².

W przeciwieństwie do neutralności emocjonalnej właściwej dla badań psychologicznych estetyczny sens tego pojęcia, uwzględniany także w innych dziedzinach nauki, jak również w życiu codziennym, kładzie nacisk na zaangażowanie emocjonalne obserwatora. Początków takiego pojmowania empatii poszukuje się w epoce romantycznej. Zwraca się uwagę, że George G. Byron pisał, iż sam staje się częścią tego, co go otacza, wchodząc ze światem zewnętrznym w kontakt emocjonalny, a Charles Baudelaire postulował stworzenie magii sugestywnej obejmującej zarazem przedmiot i podmiot, świat zewnętrzny i artystę ${ }^{3}$. Podobne poglądy pojawiały się także często wśród romantyków niemieckich.

1 Por. K. Stueber, hasło „Empathy”, [w:] Stanford Encyclopedia of Philosophy, red. E.N. Zalta, Stanford 2013, http://plato.stanford.edu/entries/empathy/ (dostęp: 18.01.2016).

2 Por. hasło „Einfühlung”, [w:] Vocabulaire d'esthétique, red. A. Souriau, Paris 1990, s. 640.

${ }^{3}$ Ibidem, s. 641. 
Teoretyczne zainteresowanie empatią występowało głównie w Niemczech na przełomie XIX i XX w. Istotnym punktem odniesienia dla tych dociekań było zastosowanie terminu „empatia” do sztuki. W najszerszym zakresie zadanie to zrealizowali Theodor Lipps, Friedrich Th. Vischer i jego syn Robert, Rudolf H. Lotze, Johannes Volkelt oraz inni badacze. W koncepcjach ich nie tylko połączone zostały konkretne problemy artystyczne z kwestiami estetycznymi, lecz także uczyniono te zagadnienia centralnymi kategoriami nauk społecznych i humanistycznych. Pojęcie empatii w tej sytuacji pełniło podstawową rolę przy ocenie dzieł sztuki, a jednocześnie mogło być traktowane jako baza przy poznawaniu ludzi jako istot obdarzonych życiem psychicznym. Wśród wymienionych autorów szczególna rola przypisywana jest R. Vischerowi, którego krótkie teksty wyprzedzały późniejsze obszerne opracowania.

Vischer uznał, że w przestrzennym rozumieniu form rozróżnić można widzenie pasywne, „bez specjalnego wysiłku”, i „o wiele bardziej aktywny proces" przyglądania się uważnie (Schauen) ${ }^{4}$. Pierwsze jest bierne i stanowi proces nieświadomy, drugie jest świadomym zabiegiem tworzenia rodzaju mapy umysłowej. Właśnie w przypadku drugiego sposobu widzenia pojawia się związek między działaniami optycznymi i kinetycznymi. Niemiecki filozof twierdzi, że gdy oglądamy coś uważnie, jest tak, jakbyśmy tego dotykali. Śledzenie wzrokowe linii przypomina wodzenie po niej końcem palca. Naoczna percepcja kształtów jest analogiczna do przebiegania po nich ręką, co pozwala wyczuwać wypukłości i wklęsłości. Na podobnej zasadzie, choć przy uwzględnieniu innych czynników, odbywa się recepcja przedmiotów jako odległych i bliskich w sensie przestrzennym. Zmysłowy odbiór nie ogranicza się więc do wzroku, a obejmuje różne zakresy doznań. Aktywizuje on części ciała inne niż oczy. Vischer rozróżnia w związku z tym bezpośrednie wrażenia i wrażenia oparte na bogatszych reakcjach. Pojawiają się one w związku z aktywizacją mięśni i odnoszeniem wrażeń wzrokowych do innych części ciała. Na przykład linia horyzontalna odpowiada rozmieszczeniu naszych oczu i dlatego wywołuje podczas oglądania uczucie przyjemności. Podobnie jest $\mathrm{w}$ przypadku percepcji regularnych form, które są zgodne z prawidłową budową ludzkiego ciała. Patrzenie ma więc pośredni związek z całością naszego organizmu. Na tej zasadzie oparte jest też zjawisko synestezji, czyli efektu wywieranego przez kolory, polegające na odnoszeniu ich do wrażeń właściwych dla innych zmysłów. Kolory mogą być np. „ciepłe” lub „zimne”, „głośne” lub „ciche”, „ciężkie” lub „lekkie”, „słodkie” lub „kwaśne”. Przezwyciężony zostaje również na tej drodze statyczny charakter obserwowanych kształtów. W przypadku odbioru empatycznego

${ }^{4}$ R. Vischer, On the Optical Sense of Form: A Contribution to Aesthetics, [w:] Empathy, Form, and Space: Problems in German Aesthetics, 1873-1893, Santa Monica 1994, s. 93-94. 
całe ciało jest do niego włączone, „cała fizyczna istota jest w ruchu”. Dlatego zdaniem R. Vischera w ciele nie ma, ściśle mówiąc, żadnego takiego procesu jak lokalizacja. A zatem każde empatyczne wrażenie ostatecznie prowadzi do „wzmocnienia lub przebudzenia ogólnego w rażen ia życia [podkreślenie w oryginale - G.Sz.]"5.

Opisany proces nie dotyczy jednak tylko bodźców aktualnie percypowanych zmysłowo, lecz obejmuje również sferę idei. Wyobrażenie według R. Vischera jest aktem, dzięki któremu mentalnie symulujemy coś, co wcześniej istniało jako treść naszych wrażeń. Dochodzi w ten sposób do wizualizacji nieobecnych przedmiotów. Wyobrażenia mogą też odnosić się do naszego „ja”. Niemiecki filozof uważa, że uważna introspekcja pozwala odkryć związki między częściami naszego ciała i sytuacjami, w jakich mogą one się znajdować, a stanami przedmiotów. Przedmioty tak ujmowane odczuwamy jako odpowiedniki różnych składników naszego ciała i ich pozycji. Sposób, w jaki przedmiot jest konstruowany w umyśle, znajduje analogię w naszej strukturze cielesnej. Nie jest to zatem tylko widzenie, gdyż dochodzi do utożsamienia naszego „ja” z formą obiektu. Przedmiot jest nieruchomy - pisał R. Vischer - a jednak „wydaje się poruszać, ale to tylko my poruszamy się w wyobraźni. Poruszamy się w i z formami [podkreślenie w oryginale - G.Sz.]"6. Ruch ten pojawia się w związku z ujmowaniem przedmiotu w analogii do naszej własnej struktury cielesnej. Wrażenia mogą więc odnosić się tylko do tego, co zewnętrzne, ale również „krystalizować się” jako „wrażenia empatyczne”. Forma ulega wtedy uwewnętrznieniu. Vischer uważał, że zostaje ona w ten sposób „rozjaśniona” i „uduchowiona”7.

Wrażenia empatyczne nie mają charakteru dowolnego. Kształtują się na zasadzie relacji przedmiotowo-podmiotowej, w której oba człony związku występują w równowadze. Kiedy dokonuję projekcji siebie na pozbawioną życia formę - pisze R. Vischer - tylko pozornie podporządkowuję jej swoją tożsamość. Dochodzi tu do dostosowania, tak jak wtedy, gdy jedna ręka ściska drugą. Dzięki temu jednak „jestem tajemniczo przeniesiony i magicznie przekształcony w coś Innego"8. Obserwując statyczny przedmiot, mogę bez wysiłku umieścić się w jego wewnętrznej strukturze, mogę zmierzyć jego rozmiary, rozległość i napięcia za pomocą moich wymiarów. Mogę swoje ciało sprowadzić do jego granic, uwzględnić jego wygięcia, czemu towarzyszyły będą odpowiednie odczucia, takie jak opresja, depresja, dążenie ku czemuś itp. Empatia sprawi, że statyczna forma będzie poruszała się, gdy pomyślimy, że za chwilę się poruszy lub że poruszała się przed chwilą.

\footnotetext{
5 Ibidem, s. 99.

${ }^{6}$ Ibidem, s. 101.

7 Ibidem, s. 102.

${ }^{8}$ Ibidem, s. 104.
} 
Uzyska ona też właściwości ekspresyjne analogiczne do postaw ciała człowieka lub różnych odmian wyrazu jego twarzy. Mamy więc w tym przypadku do czynienia z rodzajem antropomorfizacji, jaka często występuje w życiu codziennym w odniesieniu do zwierząt i roślin. 0 ile jednak w takich przypadkach mamy do czynienia z poszukiwaniem analogii między zaobserwowanymi cechami lub zachowaniami kota czy psa oraz wyglądem i sposobem bycia człowieka, o tyle w przypadku empatii dochodzi do przeniesienia siebie do wnętrza tego, co obserwowane. Następuje więc rozdwojenie nas samych, gdyż mamy poczucie, że to obserwowany przedmiot jest źródłem naszych wrażeń i doznań emocjonalnych. Vischer podkreśla więc, że w aktach empatii uczestniczy cała osoba i wszystkie jej życiowe uczucia. Jednocześnie zaś osoba ta złączona jest ze światem. Dlatego pisał wielokrotnie w związku z empatią o „impulsie panteistycznym”, polegającym na odczuwaniu naszej jedności z rzeczywistością zewnętrzną. Nie ograniczamy się wówczas do najprostszej odmiany pokrewieństwa, jaką stanowi poczucie związku z gatunkiem ludzkim, lecz kierujemy się świadomie lub nieświadomie ku jedności z całym światem9.

Główny tekst R. Vischera, na który tu wielokrotnie się powoływałem, pochodzi z $1873 \mathrm{r}$. Wyprzedził on o ponad 20 lat szeroki rozwój koncepcji empatii i jej rozległe oddziaływanie, zwłaszcza w estetyce niemieckiej. Najbardziej znaczącą postacią dla tej tendencji stał się Th. Lipps, którego krytyk kulturalny Theodor Lessig określił jako „największego żyjącego estetyka”, a brytyjska estetyczka pisząca pod pseudonimem Vernon Lee uznała za „nowego Darwina”"10 , gdyż myśl jego uważała za równie oryginalną i dalekosiężną jak koncepcje twórcy teorii selekcji naturalnej. Estetyka empatyczna sytuowana była zwykle przez jej badaczy w nurcie neokantowskim. Za jej cel uznawano znalezienie trzeciej drogi między idealizmem Heglowskim a formalizmem Johanna F. Herbarta i Roberta Zimmermanna. Przypisywano jednak tej teorii oryginalność i oczekiwano, że pozwoli ona ująć w nowy sposób szereg kluczowych zagadnień dotyczących sztuki i piękna.

Autorem, który podjął najszerszą próbę modyfikacji tradycyjnych zagadnień estetycznych w świetle teorii Einfühlung, był Th. Lipps ${ }^{11}$. Stał się on entuzjastycznym zwolennikiem koncepcji R. Vischera. W 1898 r. w tygodniku „Kunstchronik” opublikował recenzję jednej z jego prac, w której pojawił się

\footnotetext{
${ }^{9}$ Aspekt panteistyczny koncepcji empatii u R. Vischera podkreśla Helen Bridge w artykule Empathy theory and Heinrich Wölfflin: A reconsideration, „Journal of European Studies” 2010, t. 41, nr 1, s. 6. Autorka zaznacza jednak, cytując pracę P. Sterna z 1897 r., że panteizm nie jest adekwatnym psychologicznym wyjaśnieniem empatii, gdyż stanowi on nie jej źródło, lecz tylko rezultat (ibidem, s. 18).

${ }^{10}$ Por. ibidem, s. 3.

${ }^{11}$ Najważniejsza jego książka z tego zakresu - Ästhetik - ukazała się w dwóch tomach, wydanych w 1903 i 1905 r. w Hamburgu przez wydawnictwo Voss.
} 
słynny, podawany później wielokrotnie przykład wczucia odnoszący się do kolumny doryckiej ${ }^{12}$. Gdy patrzymy na nią, zdajemy sobie sprawę z ciężaru, jaki musi podtrzymywać, oraz oporu podłoża, na jakim się znajduje. Umieszczamy więc w wyobraźni siebie na miejscu kolumny i przenosimy na nią własne odczucia kinestetyczne związane z przebywaniem w takiej sytuacji - wczuwamy w nią własne doznania - co w istotny sposób wzbogaca nasze przeżycia odbiorcze. Pisząc o doświadczeniu estetycznym, niemiecki autor zakładał więc przeniesienie przez widza na percypowany przedmiot swych odczuć związanych z domniemanym przebywaniem na jego miejscu i jednoczesne uznanie, że to obserwowany obiekt jest ich źródłem. W innym tekście, zatytułowanym Ästhetik. Psychologie des Schönen und der Kunst, rozwijał ten wątek, podkreślając, że akt empatii nie rozpoczyna się od doznanego przez podmiot uczucia, które rzutowane jest na obserwowany przedmiot. Najpierw występuje poczucie związku między nimi. Jedność mojego „ja” z obcym istnieniem pojawia się jako pierwsza, świadomość dualizmu występuje dopiero jako wtórna. Empatia nie jest więc poznawczym narzędziem intelektualnym zakładającym oddzielenie poznającego podmiotu od przedmiotu poznawanego. Stanowi ona sytuację życiową pierwotną w naszym kontakcie z rzeczywistością zewnętrzną albo - jak określał to R. Vischer - niezależną od woli „skłonność i habitus”13. W przypadku kontaktu ze sztuką uzyskuje ona postać najpełniejszą. „Einfühlung pełne - pisał Th. Lipps - a więc Einfühlung estetyczne, nie jest czymś pochodnym, to ono jest w stosunku do poznania daną pierwotną". Przytaczając tę wypowiedź, Raymond Bayer podkreśla, że dla niemieckiego autora doświadczenie sztuki ma szczególne znaczenie z punktu widzenia koncepcji wczucia, a „akt estetyczny, proces estetyczny w ogóle, mieści się w tej identyfikacji ja i nie-ja"14 jako zjawisko doniosłe.

Lipps rozpatrywał problematykę empatii w wielu aspektach. Badania jego mają np. istotne znaczenie z punktu widzenia psychologicznej teorii umysłu. Sformułował też szeroko rozbudowaną koncepcję estetyczną. Nie proponował w niej odrzucenia tradycyjnej koncepcji estetyki. Opierał się na systemie ukształtowanych w niej pojęć, jednak proponował inne ich rozumienie. Na przykład, odwołując się do empatii, charakteryzował w nowy sposób piękno. Gdy moja uwaga - pisał - jest percepcyjnie skoncentrowana na przedmiocie będącym przedmiotem doświadczenia estetycznego, automatycznie projektuję na niego swe własne wcześniejsze odczucia uzyskane podczas kontaktu z obiektami, z jakimi miałem do czynienia w różnych sytuacjach życiowych, w których poznałem ich właściwości. Gdy rezultat tego procesu odczuwam jako pozytywny, oceniam przedmiot jako piękny.

\footnotetext{
${ }^{12}$ H. Bridge, op. cit., s. 4.

${ }^{13}$ R. Vischer, op. cit., s. 105.

${ }^{14}$ R. Bayer, Histoire de l'esthétique, Paris 1961, s. 348.
} 
W związku z tą zależnością Th. Lipps pisze o pozytywnej lub negatywnej empatii, traktując ją jako podstawę stwierdzenia występowania wartości estetycznej. Bayer pisał o tej koncepcji:

Psychizm wyjaśnia każdą formę świata, dając jej piękno jako duplikat lub cień. Teoria estetyczna Lippsa, jakkolwiek posiadająca charakter rozkoszy, nie jest oparta na przyjemności czystej i prostej czy nawet na hedonizmie: to działalność podmiotu jest na pierwszym planie w stosunku do przedmiotu: [następuje] reanimacja symboliczna całego istnienia. Działalność symboliczna jest w centrum problemu: liczy się intensyfikacja naszego „ja” i radość, która towarzyszy każdej wartości w działaniu ${ }^{15}$.

Uwagi te wyraźnie wskazują, że podczas konfrontacji empatii z tradycyjnymi pojęciami estetycznymi ta pierwsza dominuje. Pojęcia doświadczenia estetycznego i piękna ulegają przeformułowaniu. Piękno nie jest sprowadzane do formalnej doskonałości, a jego przeżycie nie jest kontemplacją niezależną od doświadczeń życiowych. Lipps zakładał zresztą świadomie taki porządek, charakteryzując nasze doświadczenie piękna jako „zobiektywizowane samozadowolenie".

W procesie empatii Th. Lipps nie przypisywał jednak zasadniczej roli procesom zachodzącym w ciele odbiorcy. Założenie to odnosił nawet do sytuacji, gdy mamy do czynienia ze sztukami wykonawczymi, opartymi na działaniach żywych osób. Sądził, że odtworzenie w ciele widza napięcia mięśni i nerwów, właściwego dla czynności wykonywanych przez aktorów, nie jest główną podstawą doznawanego przez niego przeżycia. Przeciwnie, w toku odbioru estetycznego dochodzi do oddalenia od sfery fizycznej w kierunku doznań intelektualnych. Analizując proces reakcji empatycznej na działania akrobaty, pisał:

Ale im bardziej mentalnie łączę się z jego ruchami, tym bardziej zawartość cielesnych wrażeń, których on doznaje, usuwa się [podkreślenia w oryginale - G.Sz.] z mojej świadomości [...] Przedmiotem mojej empatii nie jest zmaganie się i mentalne działanie, tylko umysłowa działalnośćc ${ }^{16}$.

Obserwowana akcja ulega więc w akcie odbioru empatycznego swoistej dematerializacji. Odbiorca odczuwa nie konkretną sytuację fizyczną, a samo napięcie, sam nacisk, samo dążenie ${ }^{17}$. Cielesne zjednoczenie z obserwowanym

${ }^{15}$ Ibidem.

${ }^{16}$ Th. Lipps, Ästhetik: Psychologie des Schönen und der Kunst, t. 1: Grundlegung der Ästhetik, Hamburg-Leipzig 1903, s. 131; cyt. za H. Bridge, op. cit., s. 8.

${ }^{17}$ Stanowisko to przypomina pogląd R. Vischera, który pisał, że patrząc na lecącego ptaka, powinniśmy empatycznie odczuwać nie ciało w locie, a ruch („lot ptaka poza samym ptakiem”; idem, op. cit., s. 106). 
przedmiotem stanowi tylko punkt wyjścia, natomiast podstawą doznań estetycznych są odczucia zdematerializowanych energii. Przeciwny pogląd reprezentował Heinrich Wölfflin. Problematyce empatii poświęcił on zasadniczo jedną rozprawę, swą pracę doktorską (1886), jednak poruszane w niej zagadnienia podejmował także w późniejszych książkach. Zwykle uważa się, że następowało w nich stopniowe odejście od pierwotnie przyjmowanego stanowiska. Można jednak również uznać, że nawet jeśli autor ten rezygnował z upływem czasu z konkretnych rozwiązań odnoszących się do procesu empatii, to kwestie te wpłynęły na zakres i rodzaj uwzględnianej przez niego problematyki artystycznej.

Punkt widzenia H. Wölfflina był odmienny niż w przypadku R. Vischera czy Th. Lippsa. 0 ile dla dwóch wspominanych tu wcześniej autorów sztuka była tylko jednym z obszarów, w związku z którymi uwzględniona może być problematyka empatii, o tyle dla H. Wölfflina stanowiła ona zasadniczy przedmiot zainteresowania. Odniesienie do empatii miało umożliwić rozwiązanie zagadnień teorii i historii sztuki. W tekście prezentującym takie podejście, tj. w rozprawie doktorskiej, pytanie dotyczyło głównie architektury. Często uważana była ona za dziedzinę konstrukcyjną, w której istotne są rozwiązania techniczne i uzyskany efekt czysto wizualny. Wölfflin pytał natomiast, jak możliwe jest, że formy architektoniczne zdolne są wyrażać emocje i nastroje? Efekt taki określał jako „wrażenie” wywierane na odbiorcy, natomiast za jego podstawę uważana była „ekspresja” przedmiotu. Pojawiało się jednak pytanie: czy formy tektoniczne mogą być ekspresyjne? Termin „formy tektoniczne" H. Wölfflin rozumiał szeroko, obejmując nim także wytwory sztuk stosowanych (meble, ubiory itp.), gdzie podobnie jak w architekturze nie dochodzi do przedstawiania istot obdarzonych życiem psychicznym, które ujawniają uczucia poprzez zewnętrzne objawy. Hipotezą, jaką rozważał, było uznanie, że źródłem emocji odbiorców w takich przypadkach są kinestetyczne reakcje oka, gdy śledzi znajdujące się przed nim linie. Rozwiązanie to, uwzględniane przez niektórych przedstawicieli teorii empatii, zostało jednak odrzucone, gdyż nie znajdowało potwierdzenia doświadczalnego. Nie jest prawdą, twierdził H. Wölfflin, że łatwość przesuwania się spojrzenia po układzie linearnym złożonym z płynnych linii jest podstawą przyjemności estetycznej. Szwajcarski autor proponował więc inne rozwiązanie.

Fizyczne formy - pisał - posiadają pewien charakter tylko dlatego, ponieważ my sami posiadamy ciało [podkreślenie woryginale - G.Sz.]. Gdybyśmy byli czysto wizualnymi bytami, bylibyśmy całkowicie pozbawieni możliwości estetycznej oceny fizycznego świata ${ }^{18}$.

${ }^{18}$ H. Wőlfflin, Prolegomena to a Psychology of Architecture, [w:] Art in Theory, 1815-1900. An Anthology of Changing Ideas, red. Ch. Harrison, P. Wood, J. Gaiger, Malden-Oxford-Carlton 1998, s. 712. 
To dzięki naszym fizycznym doświadczeniom możemy uchwycić ekspresję form architektonicznych. Instynktownie ożywiamy, animizujemy przedmiot, odczytując własny obraz w obserwowanym zjawisku. Potężne kolumny stymulują nas energetycznie, rozległa przestrzeń harmonizuje z naszym sposobem oddychania, asymetryczny układ jest doświadczany jako fizyczny ból, tak jakby uszkodzona była nasza kończyna albo jakby jej brakowało. Wölfflin zaznacza, że podobne doznania może wywoływać malarstwo w tych przypadkach, gdy nie przedstawia postaci ludzkich. Jako przykład podaje fragmenty architektoniczne obrazów Rubensa, „pulsujące tym samym rytmem, który ożywia jego ciała" ${ }^{19}$. Sugeruje więc możliwość przeniesienia empatycznego sposobu rozpatrywania architektury na nieożywione fragmenty przedstawione $\mathrm{w}$ obrazach, które także mogą być rozpatrywane jako ekspresyjne. Bierze również pod uwagę, o czym wspomniałem, uwzględnienia takiej analizy w odniesieniu do wytworów sztuki użytkowej.

Teoria empatii staje się w omawianej koncepcji podstawą rozpatrywania dzieł sztuki z perspektywy ekspresji. Jednak H. Wölfflin nie poszedł dalej drogą rozwijania ekspresyjnej koncepcji sztuki z uniwersalnie potraktowanego empatycznego punktu widzenia. Skoncentrował się na istotnym $w$ jego czasach problemie stylu artystycznego. Zagadnienie to u schyłku XIX w. wydawało się jednym z kluczowych pojęć metodologii historii sztuki. Style ulegały przemianom w dziejach, należało zatem pojęcie empatii (o ile miało być użyteczne przy ich analizie) poddać procesowi uhistorycznienia. Szwajcarski autor zajął sie tym zagadnieniem.

Transponując swój model empatii - pisze H. Bridge - z uniwersalnego na określony historycznie i z indywidualnego na kolektywny, definiował styl w architekturze jako ekspresję uczucia [określonego] ludu i wieku. Ludzkie ciało, w jego podwójnych uniwersalnych i historycznych aspektach, stanowi zasadniczy punkt ich połączenia. Gdy styl wyraża historycznie określony, cielesny ideał wieku, jest on niezmienną organizacją ludzkiego ciała, która gwarantuje uniwersalność naszych uczuć i form, umożliwiając nam w ten sposób rzetelną dedukcję uczucia ludzi [którzy obiekt stworzyli - G.Sz.] na podstawie naszych wrażeń związanych z formami architektonicznymi $\mathrm{z}$ innego wieku ${ }^{20}$.

Wölfflin nie zrezygnował więc z wyrażonego we wcześniejszej rozprawie przeświadczenia związanego z rolą empatii, jednak postanowił powiązać je z rozważaniami odnoszącymi się do konkretów historycznych. Zamiast zajmować się dziełem architektonicznym w sensie uniwersalnym, postanowił

\footnotetext{
${ }^{19}$ Ibidem, s. 716.

${ }^{20}$ H. Bridge, op. cit., s. 9-10.
} 
uwzględnić jego lokalizację czasową, przestrzenną i charakter stylistyczny. Chciał też zadać pytanie, w jaki sposób dzieło może stać się podstawą empatii w innych czasach, niż powstało. Zagadnienia te miały prowadzić do wypracowania nowych podstaw metodologicznych historii sztuki.

Wymienione problemy podjęte zostały przez szwajcarskiego autora w książce Renaissance und Barock: Eine Untersuchung über Wesen und Entstehung des Barockstils in Italien, która ukazała się w 1888 r. W tytule zaakcentowana została tematyka historyczno-opisowa, jednak równie istotne dla autora były kwestie teoretyczne. Dlatego rozprawę tę można potraktować jako analizę przypadków empirycznych, na podstawie których wyciągnięte zostaną wnioski ogólne. Punktem wyjścia jest empatyczne podejście do rozważanych dzieł.

Przyjmujemy wszędzie - pisał H. Wölfflin - istnienie cielesne zgodne z naszym; nadajemy sens całości świata zewnętrznego według schematów ekspresyjnych, jakich nauczyliśmy się na przykładzie naszego ciała ${ }^{21}$.

Jednak w dalszych rozważaniach uwzględnione są, opisywane na podstawie konfrontacji naszego ciała z dziełami sztuki, różne rodzaje postaw cielesnych i zachowań. Na przykład dla „postawy gotyckiej”, którą można odczuć w kontakcie i z rzeźbą, i z architekturą tego okresu, charakterystyczne jest „napięcie mięśni, precyzja ruchów, jasność, rozdrażniona dokładność, żadnego niedbalstwa, żadnej uległości, wszędzie wyraz stanowczej woli”22. Wśród cech tych występują zarówno te będące fizycznymi właściwościami człowieka, jak i te, które są psychicznymi cechami jego charakteru. Podczas odbioru dzieł gotyckich istnieje szansa zbliżenia się empatycznie do nich, ale nie oznacza to, że musimy je akceptować. Mogą one być odbierane jako obce. Kontakt z dziełami sztuki oparty na empatii może więc mieć charakter nie tylko emocjonalny, lecz także poznawczy - uświadamiamy sobie wówczas dzięki niemu inne rodzaje postaw i charakterów niż nasze własne. Historia sztuki rozpatrywana w takiej psychologicznej perspektywie polegałaby na określaniu cech stylów historycznych nie jako zbioru wizualnie dostępnych jakości, ale jako charakterystyk typów postaw psychicznych właściwych dla kolejnych epok.

W przeciwieństwie do gotyku - pisał H. Wölfflin - renesans rozwija z kolei wyraz dobrobytu: wszytko to, co było ostre i surowe, uwalnia się i odpręża, staje się spokojną energią ruchu, pełnym wigoru spokojem odpoczynku ${ }^{23}$.

\footnotetext{
${ }^{21}$ H. Wölfflin, Renaissance et Baroque, tłum. G. Ballangé, Paris 1967, s. 170.

${ }^{22}$ Ibidem, s. 171.

${ }^{23}$ Ibidem.
} 
Inną rolę pojęcia empatii w historii sztuki bierze pod uwagę Wilhelm Worringer. W przeciwieństwie do H. Wölfflina, dla którego podejście empatyczne związane było z realizacją celów odbiorcy i badacza sztuki, W. Worringer odnosi je przede wszystkim do postawy twórczej artysty. Poza tym zwracał on uwagę, że nie we wszystkich okresach dziejów sztuki takie podejście występowało. W swej słynnej rozprawie z $1911 \mathrm{r}$. Abstraktion und Einfühlung. Ein Beitrag zur Stilpsychologie pisał:

Rozważania, które następują, mają za cel wykazanie, że hipoteza, według której proces Einfühlung we wszystkich czasach i miejscach był założeniem twórczości artystycznej, jest pozbawiona podstaw. Przeciwnie, teoria Einfühlung nie stanowi dla nas żadnej pomocy w przypadku twórczości artystycznej wielu epok i wielu ludów. Nie stanowi ona, na przykład, żadnej pomocy w zrozumieniu gigantycznego zespołu dzieł sztuki, które przekraczają wąskie ramy sztuki grecko-rzymskiej i nowoczesnej sztuki zachodniej ${ }^{24}$.

Worringer zakładał więc, w przeciwieństwie do innych przedstawicieli teorii empatii, że znajduje ona zastosowanie tylko w przypadku tych odmian twórczości artystycznej, u podstaw których występuje „stosunek szczęśliwy i panteistyczny, oparty na zaufaniu między człowiekiem i zjawiskami świata zewnętrznego"25. W takiej sytuacji człowiek nie tylko wykazuje zaufanie wobec wrażeń wizualnych, lecz także odczuwa potrzebę upewnienia się odnośnie do ich cech poprzez dotyk. Kontakt empatyczny z dziełami sztuki łączy więc dane przynależne do różnych zmysłów, stwarzając wrażenie pełnego, żywego kontaktu z tym, co oglądane w świecie zewnętrznym, który wywołuje w nas przyjazne uczucia. Sytuacja taka nie występuje w przypadku nastawienia abstrakcyjnego. Worringer pisał, że

tendencja do abstrakcji jest konsekwencją głębokiego zaburzenia wewnętrznego człowieka spowodowanego przez zjawiska świata zewnętrznego i odpowiada, w dziedzinie religii, zabarwieniu silnie transcendentalnemu wszystkich przedstawieńn ${ }^{26}$.

Uważał więc, że empatia nie występuje wówczas, gdy widz nie ma zaufania do otaczającego go świata, odczuwa wobec niego lęk, czuje się wciąż zaskakiwany niedającymi się przewidzieć zjawiskami. Nie pragnie wówczas intymnego kontaktu z tym, co obce, a pragnie tylko uspokojenia, które może osiągnąć poprzez zerwanie kontaktu ze wszystkim, co go niepokoi. Wyrywa

${ }^{24}$ W. Worringer, Abstraction et Einfühlung. Contribution à la psychologie du style, tłum. E. Martineau, Paris 1978, s. 45.

${ }^{25}$ Ibidem, s. 52.

${ }^{26}$ Ibidem, s. 52. 
więc przedmioty świata zewnętrznego z kontekstu naturalnego i poddaje grze opartej na zmianie kolejności układu, oczyszcza je z tego, co nosiło cechy życia, stara się odkryć w nich sens absolutny. Jednym z objawów tej tendencji jest geometryzacja kształtów w dziele sztuki i poddawanie ich ścisłym regułom symetrii i rytmu. Sztuka taka nie rodzi się z postawy empatycznej i stosowanie wobec niej podejścia empatycznego w czasie odbioru jest nieuzasadnione.

Przedstawione założenie stało się dla niemieckiego autora podstawą do stworzenia koncepcji ewolucji dziejowej sztuki. Punktem wyjścia była twórczość artystyczna człowieka prymitywnego, który żył w ciągłym lęku przed arbitralnością i niezrozumiałością zjawisk naturalnych. Dlatego szukał ucieczki w formach abstrakcyjnych, przypisując im związek z tym, co niezmienne, niezwiązane z życiem, a więc boskie. Abstrakcja zdaniem W. Worringera rodzi się zatem nie z siły intelektu, a z poczucia jego słabości, bezradności wobec złożoności świata zewnętrznego. Podobnie jak w przypadku człowieka prymitywnego, w dalszym rozwoju sztuki zawsze, gdy odczuwana była obcość, niezrozumiałość świata, „detronizacja pychy wiedzy" prowadzi do porzucenia danych zmysłowych jako podstawy działań twórczych. Tendencja do abstrakcji ma więc źródła instynktowne. Myśl tę niemiecki autor rozwijał w późniejszej książce Formprobleme der Gotik (1927), gdzie pisał, że przez instynkt rozumie

tajemniczy prąd wewnętrzny naszego bytu, wielką irracjonalną warstwę umieszczoną pod mylącą powierzchnią zmysłów, do której dochodzimy podczas największych i najboleśniejszych medytacji ${ }^{27}$.

U podstaw leży przekonanie, „że poznanie ludzkie jest ograniczone, że świat zjawiskowy jest niezgłębiony i nie poddaje się poznaniu intelektualnemu"28. W przypadku takiego dualizmu wszelkie iluzje antropocentryczne zostają sprowadzone do nicości, a antropomorfizacja właściwa dla empatii nie znajduje uzasadnienia.

W cytowanej przed chwilą książce W. Worringer wprowadził jednak wizję przemian artystycznych zachodzących w dziejach sztuki europejskiej, która polegała na stopniowym wzbogacaniu geometrycznych, abstrakcyjnych elementów wyjściowych składnikami zaczerpniętymi z obserwacji świata zewnętrznego. Człowiek coraz lepiej zaczyna rozumieć rzeczywistość zewnętrzną i wprowadza pochodzące z niej formy do dzieł sztuki. Pogłębia się też jego zdolność do empatycznego odczuwania ich. Rozważana z tego punktu widzenia sztuka gotycka ujawnia w swym rozwoju osłabienie

\footnotetext{
${ }^{27}$ W. Worringer, L'art gothique, tłum. D. Decourdemanche, Paris 1967, s. 30.

${ }^{28}$ Ibidem, s. 30.
} 
pierwotnego dualizmu człowieka i świata, co prowadzi do stopniowego ograniczenia abstrakcyjnego charakteru linii geometrycznych i dopełnienia ich elementami opartymi na kształtach naturalnych ${ }^{29}$. Założenie to widoczne było jednak u W. Worringera już w pierwszej książce. Niemiecki autor konsekwentnie uznawał więc, że zasada Einfühlung nie jest uniwersalna. Stanowi ona podstawę twórczości artystycznej tylko w pewnych okresach i w odniesieniu do nich może być stosowana jako zasada odbioru dzieł sztuki. Worringer nie zajmował się szerzej działalnością artystyczną swoich czasów. Myśl jego podjął natomiast w odniesieniu do sztuki XX w. Herbert Read, który w książce Art Now twierdził, że we współczesnym świecie wystąpiły warunki analogiczne do charakteryzujących życie człowieka pierwotnego. Angielski autor tłumaczył w ten sposób pojawienie się tendencji abstrakcyjnych w twórczości plastycznej pierwszej połowy ostatniego stulecia ${ }^{30}$.

Teoria empatii w refleksji nad sztuką, po okresie szerokiego zainteresowania nią na przełomie XIX i XX w., w czasie kolejnych dekad była albo poddawana surowej krytyce, albo ignorowana. Ograniczę się tutaj do kilku przykładów świadczących o takiej sytuacji. Rudolf Arnheim zaliczał teorię empatii do poglądów asocjacjonistycznych i zarzucał jej nieuwzględnianie, lub też niewystarczające uwzględnianie, naturalnej więzi między postrzeganym wyglądem przedmiotu a przekazywaną przezeń ekspresją. Uważał, że kojarzenie obserwowanych cech kolumny i powstających w kontakcie z nią uczuć (takich jak duma, upór) przebiega w akcie empatii analogicznie jak proces poznawania znaczeń słów obcego języka.

Podobnie trzeba się uczyć, jaka ekspresja towarzyszy danemu stanowi ducha - pisał - człowiek bowiem zdolny jest może pojąć, że jedno wytwarza drugie, nie potrafi jednak postrzegać ekspresji równie bezpośrednio, jak kolorów czy kształtów ${ }^{31}$.

Zagadnienia związane z empatią sprowadzone więc zostały do próby rozwiązania problemu ekspresji artystycznej i próby te uznane zostały za nieudane. Nieudane, gdyż w zbyt małym stopniu uwzględniony w nich został związek między występującymi u odbiorcy emocjami a cechami bodźca wzrokowego. Arnheim był zaś zdania, że uczucie należy zobaczyć w samym utworze, gdzie występuje w postaci napięć kierunkowych między kształtami i barwami. Dlatego pisał:

${ }^{29}$ Por. ibidem, s. 80.

${ }^{30}$ Zagadnienie to omawiałem w książce Dlaczego geometria? Problemy współczesnej sztuki geometrycznej, Łódź 2004, s. 9-12.

${ }^{31}$ R. Arnheim, Sztuka i percepcja wzrokowa. Psychologia twórczego oka, tłum. J. Mach, Warszawa 1978, s. 446. Nie uważam, żeby zarzut ten był słuszny, nie mogę jednak podjąć tu szerszej polemiki z R. Arnheimem. 
Nawet w teorii empatii informacja wzrokowa miała tylko orientować widza w sytuacji, z której musiał wyciągnąć wnioski. „Kolumna dźwiga ciężar” - wiedza ta wystarczała rzekomo do wzbudzenia uczucia obciążenia, które dokładniej widz mógł sobie przypomnieć, odświeżając własne, dawne doznania. Nie umiano jasno zdać sobie sprawy, ile zależy od szczególnych, dynamicznych cech postrzeżenia ${ }^{32}$.

Z innych powodów krytykował teorię empatii Stefan Morawski. On również rozważał ją w kontekście zagadnień związanych z ekspresją, niepokoiła go zaś występująca podczas procesu Einfühlung zmiana roli dzieła sztuki oraz relacji między artystą i odbiorcą. Pisał, że

teoria empatii kładzie nacisk na duchową projekcję jaźni, podstawiając - w miejsce przeżycia estetycznego - przeżycie para-estetyczne lub doświadczenie twórcze. Teoria ta nadaje arbitralny charakter „sprzężeniu zwrotnemu" odbiorcy z dziełem sztuki, tzn. cała siła ewokacyjna przeżywanej sztuki gwarantowana jest przez odbiorcę-podmiot, nic z tej siły nie przypisuje się samemu przedmiotowi ${ }^{33}$.

Morawski uwzględniał w swym artykule różnice między przedstawicielami teorii empatii odnośnie do roli „fizjonomii” odbieranego percepcyjnie przedmiotu. Przyjmował jednak, że w stosunku do innych koncepcji przeżycia estetycznego rola ta jest w tym przypadku zawsze ograniczana. Tym bowiem, czym cieszymy się podczas empatycznego kontaktu z przedmiotem, jest nie tyle on sam, ile my sami (Ich-Qualitäten - jak określał to Th. Lipps), tzn. „nasza swobodna witalność duchowa, którą rzutujemy na obserwowany i kontemplowany taniec, dzieło architektury, namalowany pejzaż"34. Właśnie z tego powodu polski estetyk uważał, że empatia w zbyt dużym stopniu przypisuje charakter twórczy odbiorowi, ograniczając równocześnie rolę artysty. Potwierdzeniem tego faktu miało być to, że podobnie przebiega proces wczuwania uczuć w przypadku dzieł sztuki i tworów natury.

Wziąłem pod uwagę tylko dwa przykłady krytyki teorii empatii odwołujące się do problematyki estetycznej, nie uwzględniając argumentacji krytycznej, jakiej teoria ta poddawana była przez psychologów, gdyż tego aspektu koncepcji nie uwzględniam w niniejszym artykule. Warto natomiast zwrócić uwagę na fakt, że także historycy sztuki, którzy na przełomie XIX i XX w. entuzjastycznie odnosili się do możliwości rozwijania swej dziedziny w nawiązaniu do problematyki empatii, w dalszych latach wycofywali się z tego stanowiska. Przykładem może być H. Wölfflin, który w dysertacji

\footnotetext{
${ }^{32}$ Ibidem, s. 446.

${ }^{33}$ S. Morawski, Ekspresja, „Studia Estetyczne” 1974, nr 11, s. 320.

${ }^{34}$ Ibidem, s. 320.
} 
doktorskiej opowiedział się za empatycznym ujmowaniem dzieł artystycznych, w książce Renesans i barok starał się adaptować teorię empatii do analizy przejścia stylistycznego między epokami, aby następnie w swej najsłynniejszej rozprawie Kunstgeschichtliche Grundbegriffe: Das Problem der Stilentwicklung in der neueren Kunst (1915-1933) odejść od fizjonomicznego modelu (nawiązującego do roli ciała) i skoncentrować się na percepcyjnym ujmowaniu przemian stylistycznych jako modyfikacji autonomicznych, czysto optycznych środków wyrazu ${ }^{35}$.

W drugiej połowie XX w. teoria empatii miała tak złą opinię wśród estetyków i historyków sztuki, że w niektórych słownikach specjalistycznych słowo to nie było nawet uwzględniane. Sytuacja zaczęła ulegać zmianie na początku XXI w. Juliet Koss w ważnym z tego punktu widzenia artykule pisze, że po całym wieku lekceważenia i oczerniania empatia „podnosi głowę” $\mathrm{w}$ anglofonicznym dyskursie kulturalnym ${ }^{36}$. Nie polega to jednak na ogólnej rehabilitacji teorii, na nowym uzasadnieniu jej naukowej słuszności, lecz na cząstkowym uwzględnianiu jej w ostatnich dekadach przy omawianiu poszczególnych zagadnień artystycznych. Chcąc wskazać, jak zagadnienia te były różne, autorka wymienia opracowania dotyczące twórczości Edwarda Hoppera i Adolpha Menzela, architektury Franka Gehry, projektu surrealistycznego i całej dziedziny filmu. W żadnym z tych zakresów tematycznych pojęcie empatii nie uzyskało dominacji, nie stało się podstawą stworzenia szkoły naukowej. Nie powstały, o ile wiem, katedry empatii na uniwersytetach $^{37}$. Natomiast jawna promocja takiego podejścia wystąpiła w działaniach niektórych artystów, np. Karen Finley i Barbary Kruger. Druga z tych artystek kilkakrotnie umieszczała w publicznych miejscach duże napisy głoszące w różnych językach, że empatia może zmienić świat.

Charakteryzując tło współczesnego zwrotu ku problematyce empatii, J. Koss pisała:

Podobnie jak niedawny „powrót do piękna”, odrodzenie się empatii wydaje się sygnalizować gwałtowny sprzeciw wobec opozycyjnej estetyki ostatniej dekady - zdystansowanie się od rygorystycznego intelektualizmu dyskursu poststrukturalistycznego i lojalności polityki tożsamości. Współczesne odwoływanie się do tego pojęcia może też być związane z jego orientacją

${ }^{35}$ Warto jednak zwrócić uwagę, że H. Bridge, poddając wnikliwej analizie kolejne etapy rozwoju koncepcji H. Wölfflina, wyraża opinię, że nigdy nie porzucił on „idei sztuki jako ekspresji, a odwrócił się od modelu ekspresji opartej na ciele jako pośredniku między formą a uczuciem" (eadem, op. cit., s. 13). Autorka wskazuje też na analogie między poglądami wyrażanymi w Podstawowych pojęciach historii sztuki i twierdzeniami Th. Lippsa.

${ }^{36}$ J. Koss, On the Limits of Empathy, „The Art Bulletin” 2006, t. 88, nr 1, s. 139.

${ }^{37}$ Pod tym względem sytuacja jest odmienna niż w przypadku performatyki, która stymulowała i stymuluje wiele naukowych działań organizacyjnych, takich jak tworzenie jednostek badawczych, wydawanie czasopism i serii wydawniczych. 
interdyscyplinarną. Jako dyskusja o zagadnieniach odbioru [spectatorship] było stosowane do sztuki, architektury, literatury, filmu i teatru; natchnęło zarówno dyskurs polityczny, jak i estetyczny w Stanach Zjednoczonych, gdzie jeden prezydent żądał, żeby czuć cierpienie swego narodu, a następny był orędownikiem „współczującego konserwatyzmu”. Empatia wydaje się obiecywać konstruktywne teoretyczne podejście doceniające zarówno to,co emocjonalne, jak i to, co racjonalne, uwzględnia rozumienie i dopuszcza możliwość przerzucenia mostu między radykalnie odmiennymi sytuacjami podmiotu, zarówno w obrębie, jak i w poprzek okresów historycznych i sfer geograficznych ${ }^{38}$.

Nie mogę tu szerzej odnieść się do wielozakresowości przejawów zainteresowania problematyką empatii ani tym bardziej śledzić przyczyny wystąpienia tego zjawiska. Dlatego ograniczę się do wskazania kilku przykładów powrotu do tego zagadnienia w zakresach refleksji nad sztuką nieuwzględnionych w przeglądzie dokonanym przez J. Koss.

Wśród odmian empatii analizowanych dawniej przez estetyków, a także wśród zagadnień podejmowanych w związku z nią przez historyków sztuki, istotną rolę pełniła architektura. Współcześnie odniesienia do niej są brane pod uwagę przede wszystkim w kręgu rozważań nad architekturą performatywną. Reprezentujący ten nurt autorzy piszą o „architekturze jako performansie"39, a podstaw dla uzasadnienia tego sformułowania poszukują m.in. w założeniach teorii empatii. Szerszego znaczenia nabiera natomiast zagadnienie empatycznego odbioru malarstwa i rzeźby. Zainteresowanie tą problematyką stymuluje dodatkowo możliwość odniesienia omawianej problematyki do filmu.

Ważnym autorem rozwijającym współcześnie tematykę empatii w zakresie interpretacji wizerunków ludzkich w malarstwie i rzeźbie jest David Freedberg. Nie traktuje on połączenia sztuki ukazującej postacie ludzkie z ideą empatii jako odkrycia. Przeciwnie, wielokrotnie wskazuje, że takie jej traktowanie jest głęboko zakorzenione w tradycji refleksji nad sposobami oddziaływania wizerunków, a poza tym było wielokrotnie problematyzowane przy użyciu innych terminów. Przykładem może być koncepcja invisibilita per visibilita. Chodzi w niej o medytację religijną, której formy uzależnione są od przedstawień malarskich lub rzeźbiarskich. Wytwarzane są wówczas wizerunki mentalne. Celem medytacji jest uchwycenie tego, co niewidzialne, nieobecne - czy to w sensie historycznym, czy duchowym. Koncepcja ta zakładała, że aby ów cel osiągnąć, korzystnie jest zacząć od koncentracji na tym, co widzialne. Oglądane wizerunki nie powinny jednak tylko pobudzać naszej pamięci, lecz również skłaniać do empatii.

\footnotetext{
${ }^{38}$ J. Koss, op. cit., s. 139.

${ }^{39}$ Por. Architecture as Performing Art, red. M. Feuerstein, G. Read, Burlington 2013.
} 
A ponieważ nasze umysły - pisze D. Freedberg - są w przeważającej mierze trywialne i nie wykazują skłonności mistycznych, niezdolne wznieść się na poziom abstrakcji i czystej duchowości, jakaż może być lepsza droga do zrozumienia całości wkładu cierpienia i czynów Chrystusa niż przez wynikające z empatii emocje (w końcu jego cierpienie było konsekwencją wcielenia w postać człowieka)? Staje się nam bliższy i łatwiej jest nam kształtować nasze czyny na wzór jego życia i życia jego świętych, kiedy z nimi cierpimy - a najlepiej robić to z pomocą wizerunków. Dochodzimy do współodczuwania, koncentrując się na wizerunkach Chrystusa i jego świętych oraz na ich cierpieniu. Taki pogląd stoi za całą tradycją medytacji opartej na empatii ${ }^{40}$.

Empatię występującą w przypadku odbioru dzieł malarskich i rzeźbiarskich amerykański autor traktuje jako „starą teorię" o szerokim, pozaartystycznym sensie. Wiąże ją m.in. z praktykami medytacyjnymi, w których pełni ona istotną rolę ze względu na stwarzanie „poczucia bliskości [...] tego, co boskie" $^{\prime \prime 1}$. Freedberg zwracał jednak uwagę, że empatia taka, mimo istotnego celu duchowego, odnosiła się także do ciała i odczuć z nim związanych. Na przykład w przypadku wizerunków przedstawiających ukrzyżowanie Chrystusa nie trzeba być specjalnie pobożnym, by „odczuć grozę na widok przebitego ciała, które ugina się i rozstępuje jak nasze własne ciało"42.

Sposób pojmowania empatii przez D. Freedberga wydaje się pod niektórymi względami różnić od omawianych na początku tego artykułu poglądów R. Vischera, Th. Lippsa czy H. Wölfflina. Należałoby poddać w związku z tym bardziej szczegółowej analizie, czy różnice te są konsekwencją koncentracji na odmiennym materiale badawczym, czy dotyczą innego sposobu pojmowania empatii. Freedberg ma świadomość tej odmienności, choć nie przedstawia szczegółowego spisu różnic. Zwraca jednak uwagę na to, że w swych rozważaniach skupia się na

sposobach mówienia o zachowaniu, które sami widzowie potrafią rozpoznać i dostrzec, a także o zachowaniu i interakcji, które nie zachodzą, jeśli brak jest przedmiotu figuralnego ${ }^{43}$.

Daje w ten sposób wyraz decyzji, że centralnego przedmiotu jego uwagi nie będzie stanowiło ożywianie poprzez projekcję nieantropomorficznych elementów w dziełach sztuki, np. kolumn ${ }^{44}$. Można uznać, że decyzja ta

${ }^{40}$ D. Freedberg, Potęga wizerunków. Studia z historii i teorii oddziaływania, tłum. E. Klekot, Kraków 2005, s. 166.

${ }^{41}$ Ibidem, s. 171.

${ }^{42}$ Ibidem, s. 203.

${ }^{43}$ Ibidem, s. 24.

${ }^{44}$ Freedberg pisze: „Będę więc oczywiście musiał się zająć także »subiektywnymi stanami odbiorcy, projektowanymi na dzieło sztuki [jeśli nie do jego wnętrza - G.Sz.]«" (ibidem). 
w pewnym stopniu ogranicza formułowane wcześniej wobec teorii empatii zarzuty dotyczące nieuwzględniania „fizjonomii” obserwowanego motywu artystycznego. Jeśli na obrazie widzimy wizerunek człowieka, relacja „wewnętrznej mimikry” czy sympatii wobec przedstawionej osoby rodzi się w sposób bezpośredni. Nie ma potrzeby asocjacji, na których rolę zwracał uwagę R. Arnheim, poddając z tego powodu krytyce teorię empatii. Dlatego D. Freedberg może napisać, że właściwa dla jego rozważań empatia traktowana jest „w rygorystycznie fenomenologiczny sposób”45.

$\mathrm{Na}$ ważne uzupełnienie powodów doniosłości problematyki empatii D. Freedberg zwraca uwagę w artykule, w którym odnosi interesującą go problematykę doświadczenia estetycznego wizerunków do ustaleń „neuroestetyki”. Określa tak dziedzinę nauki łączącą badania neuroscjentystyczne $\mathrm{z}$ refleksją nad sztuką ${ }^{46}$. Sugestie związane z możliwością wykorzystania w tym zakresie wyników empirycznych badań nad funkcjonowaniem mózgu wysuwali już wcześniej prowadzący je naukowcy. Istotną rolę z tego punktu widzenia przypisywali mechanizmom zwierciadlanym (mirroring mechanisms).

Ilekroć patrzymy - pisał Vilayanur S. Ramachandran - jak ktoś coś robi, uaktywniają się neurony, które nasz mózg wykorzystałby do zrobienia tego samego - jakbyśmy sami to robili. Jeśli widzimy, że ktoś jest kłuty igłą, nasze neurony bólowe reagują tak, jakbyśmy sami byli kłuci ${ }^{47}$.

Często czujemy efekt obserwowanego ukłucia w naszej kończynie. Ciekawe jednak, że podobne odczucia występują u ludzi, których kończyny zastąpione zostały fantomami. Osoby takie, obserwując, jak ktoś gładzi i poklepuje czyjąś rękę, nie tylko widziały, lecz również czuły w swoim fantomie to, co dzieje się z ręką, na którą występowało oddziaływanie.

Moim zdaniem - pisze V.S. Ramachandran - wynika to z tego, że [...] neurony lustrzane uaktywniały się w normalny sposób, ale nie było już sygnału zerowego z ręki, żeby je zawetować. [...] Pomyślcie tylko: być może jedyną rzeczą, jaka oddziela naszą świadomość od cudzej, jest nasza skóra! ${ }^{48}$.

Efekt ten określił jako „hiperempatię nabytą”.

45 Ibidem.

46 D. Freedberg, V. Gallese, Motion, emotion and empathy in esthetic experience, „Trends in Cognitive Sciences" 2007, t. 11, nr 5, s. 197.

${ }^{47}$ V.S. Ramachandran, Neuronauka o podstawach człowieczeństwa. O czym mówi mózg?, tłum. A. i M. Binderowie, E. Józefowicz, Warszawa 2012, s. 145.

${ }^{48}$ Ibidem, s. 146. 
Freedberg i Vittorio Gallese wyprowadzają daleko idące konsekwencje badań neuroscjentystycznych. Zwracają oni uwagę na zdolność do preracjonalnego ujmowania sensu działań, emocji i wrażeń innych związaną z cielesnymi symulacjami - funkcjonalnymi mechanizmami, dzięki którym to, co obserwowane u innych, aktywizuje nasze wewnętrzne przedstawienia stanów ciała. Angażujemy się w ten sposób - poprzez działania zachodzące w naszym organizmie - w obserwowane emocje i wrażenia. Gdy patrzymy na Jeńców Michała Anioła, reakcja nasza przebiega jako odczuwalna aktywizacja mięśni odpowiadających obserwowanemu napięciu mięśniowemu przedstawionych postaci. Podobnie jest w przypadku Okropności wojny Francisca Goi. Empatyczne reakcje polegają na fizycznych odczuciach umiejscowionych w tych częściach ciała, które są oglądane jako pobudzone czy zagrożone ze względu na stosowany przymus lub bezpośrednie niebezpieczeństwo uszkodzenia. Ta „fizyczna empatia”, jak ją określają autorzy artykułu, ulega łatwo przemianie w „uczucie empatii dla emocjonalnych konsekwencji sposobów, w jakie ciało jest uszkadzane lub okaleczane" ${ }^{\prime 49}$.

Dalszą konsekwencję stanowi przeniesienie tej koncepcji doświadczenia estetycznego na obszar recepcji dzieł sztuki, w których nie występują postacie ludzkie. Autorzy wspominają o skręconych kolumnach romańskich, a także o malarstwie nieprzedstawiającym Jacksona Pollocka i Lucia Fontany. U pierwszego z tych artystów układy plam barwnych na płótnie ewokowałyby ruchy ciała wykonywane przez malarza w czasie pracy nad obrazem, natomiast u drugiego nacinane obrazy byłyby zbieżne $\mathrm{z}$ odczuciem gwałtownych gestów, w wyniku których powstały otwory.

Ten mechanizm motorycznej symulacji - piszą D. Freedberg i V. Gallese - połączony z emocjonalnym rezonansem, który zostaje wyzwolony, jak było sugerowane przez Lippsa, jest prawdopodobnie decydującym składnikiem estetycznego doświadczenia przedmiotów w dziełach sztuki: nawet martwa natura może być „ożywiona” przez wcieloną symulację, jaką wywołuje w mózgu obserwatora ${ }^{50}$.

Zagadnienie wczucia w odniesieniu do martwych natur i pejzaży podjął Michael Fried w książce nawiązującej do twórczości A. Menzela ${ }^{51}$. Praca ta, rozpatrywana z perspektywy współczesnego zwrotu empatycznego, jest istotna zarówno ze względu na podjętą tematykę, jak i sposób badawczego podejścia do problemu. Tekst M. Frieda odbiega od sposobu pisania na temat empatii przyjętego w opracowaniach z przełomu XIX i XX w.

${ }^{49}$ D. Freedberg, V. Gallese, op. cit., s. 197.

${ }^{50}$ Ibidem, s. 201.

${ }^{51}$ M. Fried, Menzel's Realism: Art and Embodiment in Nineteenth-Century Berlin, New Haven 2002. 
Ówcześni autorzy dążyli do zobiektywizowania problematyki, przyjmując odmianę dyskursu analogiczną do wypowiedzi przedstawicieli innych kierunków filozofii, psychologii lub historii sztuki. Tymczasem M. Fried uprawia refleksję wywodzącą się z doświadczenia interakcji między nim jako odbiorcą a dziełami sztuki. Bierze pod uwagę swe własne doznania cielesne w kontakcie z poszczególnymi obrazami. Przyjmuje poetykę nie tyle opartą na twierdzeniach i weryfikowaniu ich, ile na opisie własnych doświadczeń, a także samokwestionowaniu, zwracając się często bezpośrednio do czytelnika, jak gdyby w celu podjęcia konwersacji. Można to uznać za celowy zabieg perswazyjny mający na celu przekonanie do zasadności opisywanych procesów empatycznych. Będą one wówczas, jak pisze Ellen J. Esrock,

retorycznymi strategiami wykorzystywanymi przez Frieda do stworzenia wrażenia szczerej komunikacji, która czyni czytelników otwartymi na jego propozycje, a nawet zachęca ich do podejmowania aktów wcielenia [własnych emocji - G.Sz. $]^{52}$.

Można jednak również (propozycja ta nie wyklucza powyższej) uznać taki sposób pisania za najbardziej uzasadniony w odniesieniu do problemów empatii, które z trudem poddają się ściśle naukowemu ujęciu. Przy próbach uogólnionej analizy doświadczeń cielesnych, jakie w ich przypadku są podstawą wypowiedzi, umyka wiele aspektów, które M. Fried stara się wziąć pod uwagę w swej książce.

Jedną z takich kwestii jest zmienność cechująca konkretne przypadki obejmowane ogólnym pojęciem empatii. Już wcześniej zwracano uwagę na nieostrość granic tego określenia i różnorodność zjawisk nim obejmowanych. Zabiegiem, który w związku z tym stosowano, było np. wskazywanie na różnice między tym, co oznaczają terminy „empatia” i Einfühlung ${ }^{53}$. Rozwiązywało to jednak problem tylko częściowo. Fried akceptuje tę nieostrość, a nawet uznaje ją za konieczną w sytuacji, gdy samo opisywane przedsięwzięcie obejmuje wiele aktów wyobrażeniowych projekcji cielesnych doświadczeń.

Rozważania prowadzone przez amerykańskiego autora pozwalają subtelniej niż w przypadku wcześniejszego, generalizującego podejścia uchwycić subtelne zagadnienia związane z wcieleniem, projekcją, symulacją, rolą wyobraźni itp. Jednym z opisywanych przez niego problemów jest to, że gdy

przedstawiona scena quasi-hipnotycznie oddziałuje na widza, który od razu zaczyna „przenikać” przestrzeń obrazu i empatycznie odpowiada na

${ }^{52}$ E.J. Esrock, Embodying Art: The Spectator and the Inner Body, „Poetics Today” 2010, t. 31, nr 2, s. 221.

${ }^{53}$ Por. na ten temat uwagi zawarte w Vocabulaire d esthétique..., s. 640-641. 
jej zawartość, odkrywa on (mówię teraz o sobie), że jest ledwie zdolny do oderwania swych oczu od płótna ${ }^{54}$.

Inna sytuacja, pojawiająca się w czasie aktów empatii, związana jest z

percepcyjnym i imaginatywnym wysiłkiem, jaki jest wymagany od widza w celu spełnienia aktu widzenia (i wywołania tego prawie hipnotycznego stanu), kończąc sięożywieniem lub reanimacją piktorialnego pola za pomocą energii projekcyjnych $[\ldots]^{55}$.

Różnica między obu sytuacjami dotyczy, z pewnym uproszczeniem, koncentracji albo na tym, co zewnętrzne w stosunku do odbiorcy (rzeczywistości przedstawionej na obrazie i jej składnikach stymulujących akty empatii), albo na stronie wewnętrznej, na wysiłku myślowym, od stopnia aktywizacji którego zależy „ożywienie” tego, co przedstawione. Dokonany przez M. Frieda wybór malarstwa A. Menzela jako przedmiotu rozważań prowadzonych w książce był niezwykle trafny, gdyż w obrazach tych przedstawione są zwyczajne sceny z życia, takie jak dziedziniec z tyłu wiejskiego domu albo pokój z otwartymi drzwiami balkonowymi, przez które wpada światło słoneczne. Wydają się one jednak przepełnione życiem, zdają się oddychać. Czy to poczucie „oddychania” przestrzeni pochodzi z obserwacji cech obrazu, czy zostaje wczute w przedstawioną scenę przez odbiorcę? Rozstrzygającej odpowiedzi na to pytanie nie można udzielić. Można tylko rozważać problem. Fried opowiada się za refleksyjnym podejściem do tego zadania, niestroniącym od uwzględnienia własnych doświadczeń.

Inne rozwiązanie, sformułowane w nawiązaniu do książki M. Frieda, proponuje E.J. Esrock. W obszernym artykule The Spectator and the Inner Body sugeruje możliwość połączenia wspomnianego wyżej zagadnienia z psychologicznym problemem eksterocepcji i interocepcji. Pierwszy z tych terminów określa formę czucia, której źródłem jest bodziec położony poza ciałem. W drugim przypadku chodzi o odczucia powstające na skutek pojawiających się w ciele informacji o stanie narządów wewnętrznych (np. temperaturze ciała, odczuciach bólu, głodu, pragnienia, wrażeniach mięśniowych i trzewnych ${ }^{56}$. W przypadku empatii obydwa rodzaje czynników wchodzą w grę w trudnych do określenia relacjach. Odniesienie do aparatu pojęciowego współczesnej psychologii pozwala jednak, podobnie jak w przypadku wspomnianej wyżej neuroestetyki, wprowadzić rozważania w ramy nowych kontekstów.

\footnotetext{
${ }^{54}$ M. Fried, op. cit., s. 225.

${ }^{55}$ Ibidem, s. 225.

${ }^{56}$ Por. A.M. Colman, Słownik psychologii, Warszawa 2009, s. 187, 281-282.
} 
Jeśli rozumiemy Friedowskiego widza - pisze E.J. Esrock - jako projektującego swoją własną cielesną interocepcję, wtedy musimy zapytać, jakich jakości widz doświadcza przez tę projekcję. Proponuję, żeby najbardziej oczywistą jakością, jaką kojarzymy z naszym wewnętrznym ciałem, było uczucie bycia żywym, gdyż interocepcyjna świadomość ciała jest świadomością tego, co ożywione, żywe. Nieodłączna od bycia żywym jest zdolność do samoinicjujących ruchów ${ }^{57}$.

W ten sposób z punktu widzenia współczesnej psychologii zinterpretowana zostaje tradycyjna dla teorii empatii zasada animizacji.

Trudno w tej chwili powiedzieć, czy zwrot empatyczny zauważalny we współczesnej refleksji nad sztuką osiągnie zakres porównywalny z innymi zwrotami w naukach o kulturze, takimi jak zwrot interpretatywny, performatywny, refleksyjny, postkolonialny, przestrzenny, translatologiczny lub ikoniczny. Pisząc o zakresie, mam na myśli z jednej strony liczbę naukowców zainteresowanych problemem, z drugiej liczbę obszarów badawczych, w jakich się ujawni. Uważam jednak, że od tych kryteriów ilościowych ważniejsze jest, czy teoria empatii w nowych interpretacjach ma szansę spełnić w refleksji nad sztuką rolę podobną do wyżej wymienionych rodzajów zwrotów kulturoznawczych. Problem ich doniosłości Doris Bachmann-Medick sprowadzała do zagadnień operacyjnych podejść oraz kategorii analitycznych. W tych zakresach każdy zwrot proponował odmienny sposób ogniskowania i przenoszenia punktów ciężkości, a także metody pozwalające na sprawdzanie założeń badawczych wraz z ich usytuowaniem w określonym dyskursie teoretycznym ${ }^{58}$. Uważam, że teoria empatii spełnia takie warunki zwrotu. Stanowi ona przejaw odwrotu od „wielkich narracji” i „wielkich paradygmatów”, nie dostarcza określonego „obrazu świata”, otwiera natomiast pole dla eksperymentów w postaci „play of ideas free of authoritative paradigms" ${ }^{\prime 59}$. W dzisiejszej rzeczywistości nauk humanistycznych zwrot empatyczny okazuje się sposobem mówienia o sztuce, który cechuje wzmożona uwaga skierowana ku jej stronom i aspektom niedocenianym. Uświadamia on też, że jest wiele innych niż zwykle uwzględniane sposobów pojmowania tego samego przedmiotu, co wzbogaca możliwości widzenia, myślenia i przetwarzania ${ }^{60}$.

${ }^{57}$ Ibidem, s. 229.

${ }^{58}$ D. Bachmann-Medick, Cultural Turns. Nowe kierunki w naukach o kulturze, tłum. K. Krzemieniowa, Warszawa 2012, s. 8.

${ }^{59}$ Ibidem, s. 20.

${ }^{60}$ Ibidem, s. 30. 


\section{BIBLIOGRAFIA}

Architecture as Performing Art, red. M. Feuerstein, G. Read, Burlington 2013.

Arnheim R., Sztuka i percepcja wzrokowa. Psychologia twórczego oka, tłum. J. Mach, Warszawa 1978.

Bachmann-Medick D., Cultural Turns. Nowe kierunki w naukach o kulturze, tłum. K. Krzemieniowa, Warszawa 2012.

Bayer R., Histoire de l'esthétique, Paris 1961.

Bridge H., Empathy theory and Heinrich Wölfflin: A reconsideration, „Journal of European Studies" 2010, t. 41, nr 1, s. 3-22.

Colman A.M., Słownik psychologii, Warszawa 2009.

Esrock E.J., Embodying Art: The Spectator and the Inner Body, „Poetics Today” 2010, t. 31, nr 2, s. 217-250.

Freedberg D., Potęga wizerunków. Studia z historii i teorii oddziaływania, tłum. E. Klekot, Kraków 2005.

Freedberg D., Gallese V., Motion, emotion and empathy in esthetic experience, „Trends in Cognitive Sciences" 2007, t. 11, nr 5, s. 197-202.

Fried M., Menzel's Realism: Art and Embodiment in Nineteenth-Century Berlin, New Haven 2002.

Koss J., On the Limits of Empathy, „The Art Bulletin” 2006, t. 88, nr 1, s. 139-157.

Lipps Th., Ästhetik: Psychologie des Schönen und der Kunst, t. 1: Grundlegung der Ästhetik, Hamburg-Leipzig 1903.

Morawski S., Ekspresja, „Studia Estetyczne” 1974, nr 11, s. 315-335.

Ramachandran V.S., Neuronauka o podstawach człowieczeństwa. O czym mówi mózg?, tłum. A i M. Binderowie, E. Józefowicz, Warszawa 2012.

Stanford Encyclopedia of Philosophy, red. E.N. Zalta, Stanford 2015, http://plato.stanford. edu/ (dostęp: 18.01.2016).

Sztabiński G., Dlaczego geometria? Problemy współczesnej sztuki geometrycznej, Łódź 2004.

Vischer R., On the Optical Sense of Form: A Contribution to Aesthetics, [w:] Empathy, Form, and Space: Problems in German Aesthetics, 1873-1893, Santa Monica 1994.

Vocabulaire d'esthétique, red. A. Souriau, Paris 1990.

Wölfflin H., Prolegomena to a Psychology of Architecture, [w:] Art in Theory, 1815-1900. An Anthology of Changing Ideas, red. Ch. Harrison, P. Wood, J. Gaiger, Malden-Oxford-Carlton 1998, s. 711-717.

Wölfflin H., Renaissance et Baroque, tłum. G. Ballangé, Paris 1967.

Worringer W., Abstraction et Einfühlung. Contribution à la psychologie du style, tłum. E. Martineau, Paris 1978.

Worringer W., L'art gothique, tłum. D. Decourdemanche, Paris 1967. 


\section{SUMMARY}

\section{Empathy in art: past and present}

At the turn of the $19^{\text {th }}$ and $20^{\text {th }}$ centuries, scholars began to include the notion of empathy in their reflections on art; such a perspective was aimed at revaluing basic aesthetic issues. The article summarizes the core principles of the concept of empathy employed in the field of fine arts, and examines its use in the theories of such scholars as Robert Vischer, Theodor Lipps, Heinrich Wölfflin and Wilhelm Worringer. This will be followed by a brief consideration of the reasons why this idea was rejected by the researchers on art in the second half of the $20^{\text {th }}$ century. Against this background, my article will pose the question regarding a return to the concept of empathy in the reflection on the visual arts in this century. Its symptoms have been pointed out by some Anglophone authors (such as Juliet Koss). One should, however, note the differences in the new approach. The former biophysiological background has been replaced with references to contemporary research on brain functioning. Instead of concentrating on the expressive character of architecture, scholars explore e.g. an empathetic response to human images (David Freedberg) or to landscapes and still lifes (Michael Fried). 